Int. Archs Allergy appl. Immun. 1983;71:I-IV

\title{
Contents, Vol. 71, 1983
}

\section{No. 1}

Original Paper

A Simple Solid Phase Radioimmunoassay Specific for Human

C3b to Detect C3b Receptors on Human Lymphoblastoid

Cell Surfaces

Barel, M.; Charriaut, C; Frade, R 1

Studies on a New Lymphocyte Mitogen from Pollen Aqueous

Extract: Induction of Proliferation in Human and Rodent

Lymphocytes

Anfosso, F.J.; Guillard, P.M.; Charpin, J.P 6

Effect of Agents Which Block Steroid Receptor-DNA Interaction on Anti-DNA Antibody Titers

in Sera of Patients with

Systemic Lupus Erythematosus

Kelly, R.H.; Ostergren, K.A.; Rosenbaum, L 15

Antigen- and IgE Class-Specific Suppression Mediated by T

Suppressor Cells of Mice Treated with Glutaraldehyde-

Polymerized Ovalbumin

HayGlass, K.T.; Strejan, G.H 23

IgE on Rat Pleural and Peritoneal Mast Cells; Relation to

Serum $\operatorname{IgE}$

Toorenenbergen, A.W. van; Swieten, P. van; Aalberse, R.C. 32 Cerebrospinal Fluid

Granulocytes in Bacterial Meningitis Have

E Receptors

Næss, A 37

Comparative Studies on Tree-Pollen Allergens. V. Immuno-

chemical Mapping of the Antigens and Allergens of Birch

Pollen Extract (Betula verrucosa)

Vik, H.; Elsayed, S.; Apold, J 40

Comparative Studies on Tree-Pollen Allergens. VI. The Effect

of Thermal Denaturation on the Reactivity of Birch Pollen

(Betula verrucosa) Allergens

Vik, H.; Lillehaug, J.R

The Development and Validation of Radioallergosorbent Tests for the Detection of Specific Human IgE Antibody Directed against Laboratory Animal Urinary Proteins

Edwards, R.G.; Lee, D.; Beeson, M.F.; Dewdney, J.M.;

Spackman, D.A 53

BL-5255 II: Effects on Release and Smooth Muscle Activity of Mediators of Immediate Hypersensitivity Reactions 
Reed III, F.C.; Newball, H.H.; Siminoff, P 59

Enhancement of in vitro and in vivo Antitumor Activity by

Coid Factor (6-6'-Dimycolate of Trehalose) Administered

Suspended in Saline

Orbach-Arbouys, S.; Tenu, J.P.; Petit, J.F 67

Carrier Requirement for Development of Acute Experimental

Hypersensitivity Pneumonitis in the Rabbit

Butler, J.E.; Richerson, H.B.; Swanson, P.A.; Suelzer, M.T.;

Kopp, W.C 74

Allergens of Alternaria: Further Characterization of a Basic

Allergen Fraction

Budd, T.W.; Kuo, C.Y.; Cazin, J., Jr.; Yoo, T.J 83

Regulation of Lymphocyte Responses in Cancer Patients. I. Study of Cell-Surface Gangliosides by Cholera Toxin and Their Induction of Impaired Activation Tsuru, S.; Nomoto, K.; Aiso, S.;

Ogata, T.; Zinnaka, Y. .

Short Communication

9396

Difference of the IgE Memory Cells in SJL and BALB/c Mice

Hirano, T.; Ovary, Z

Book Reviews

No. 2

Original Paper

A Reevaluation of the Concanavalin A Induced Suppressor

Cell Assay in Man

Knaab, S.; Jeannet, M 97

Cyclic AMP Levels during Stimulation and Inhibition of Hista -

mine Release from Rat Mast Cells by the Calmodulin

Inhibitor Trifluoperazine

Aim, P.E 103

Studies in Immunodermatology. IX. Effect of Organic Solvents and Enzymes on the Reactivity of Stratum corneum Antigens Kumar, V.; Rogozinski, T.; Beutner, E.H.; Jablonska, S. . 112

Studies on the Paul-Bunnell Antigen-Antibody System. HI.

Detection of a Paul-Bunnell-Related Antigen in Syphilis

and Leprosy

Morito, T.; Kano, K; Milgrom, F 117

IgG4 Antibodies in Patients with House-Dust-Mite-Sensitive Bronchial Asthma: Relationship with Antigen-Specific Im-munotherapy

Nakagawa, T.; Takaishi, T.; Sakamoto, Y.; Ito, K; Miya

moto, T.; Skvaril, F 122

Antigen Release from Thermoactinomyces vulgaris by Lyso-zyme Treatment

Ojanen, T.H.; Naukkarinen, A.H.M.; Katila, M.-L.; Terho,

E.O.; Mäntyjärvi, R.A126

Time Course of Morphometric Changes after Acute Allergic

Bronchoconstriction in the Guinea Pig

Baumal, R.; Hooi, C; McAvoy, D.; Broder, 1 
Activation of the Complement System and Accumulation of Hemoglobin-Haptoglobin Complexes in Plasma during an Adverse Reaction to Penicillin Treatment (with 1 color plate) Brandslund, L; Svehag, S.-E.; Teisner, B.; Hyltoft Peter

son, $\mathrm{P} 137$

The Use of Particle Counting Immunoassay (PACIA) for the Titration of Specific Antibodies. Application to Sera from Honeybee Venom-Desensitized Patients Magnusson, C.G.M.; Djurup, R.; Weeke, B.; Masson, P.L. . 144

Contents

III

Analysis of Chemotactic Factor Generation in Clq-Deficient

Sera

Leyva-Cobián, F.; Clerici, N 151

Airway Response to Leukotriene D4 in Rhesus Monkeys

Patterson, R.; Harris, K.E.; Smith, L.J.; Greenberger, P.A.;

Shaughnessy, M.A.; Bernstein, P.R.; Krell, R.D 156

In vitro Generation of Mast Cell-Like Cells from Human

Peripheral Mononuclear Phagocytes

Czarnetzki, B.M.; Krüger, G.; Sterry, W 161

Correlation between Low Levels of Maternal IgG Antibodies to

R Protein and Neonatal Septicemia with Group B Strepto

cocci Carrying R Protein

Linden, V.; Christensen, K.K.; Christensen, P 168

Evaluation of the Pulmonary Immune Response by Analysis of Bronchoalveolar Fluids Obtained by Serial Lung Lavage Hill, J.O.; Bice, D.E.; Hams, D.L.; Muggenburg, B.A. ... 173

Monoclonal Antibodies against Gastrointestinal Tumour-

Associated Antigens Isolated as Monosialogangliosides

Lindholm, L.; Holmgren, J.; Svennerholm, L.; Fredman, P.;

Nilsson, O.; Persson, B.; Myrvold, H.; Lagergård, T 178

Short Communications

Half-Life of Murine IgE Antibodies in the Mouse

Hirano, T.; Horn, C; Ovary, Z 182

A New Method of Testing Anti-Allergic Drugs

Koltai, M 185

Radiation-Resistant IgE-Secreting Cells in the Mouse Suscepti

bility to Suppressor T Cells

Holt, P.G.; Leivers, S. 188

Book Reviews $\quad 191$

No. 3

Original Paper

LDH Isoenzyme Distribution in Human Eosinophils

De Simone, C; Ferrari, M.; Sorice, F 193

Studies in Immunodermatology. X. Detection of Glycoprotein-

and Carbohydrate-Type Stratum corneum Antigens by Im-

munofluorescence: Conversion Effects of Enzymes and

Trauma 
Dabski, K.; Beutner, E.H.; Jablonska, S 200

Studies in Immunodermatology. XI. Demonstration of Allospecificity of Stratum corneum Antibodies and Antigens by Indirect Immunofluorescence

Dabski, K.; Beutner, E.H.; Jablonska, S 210

Leukotriene C4 and Dimethylphenylpiperazinium-Induced Responses in Canine Airway

Tracheal Muscle Contraction and

Fluid Secretion

Johnson, H.G.; McNee, M.L.; Johnson, M.A.; Miller, M.D. 214 Types of Immune Complexes in the Ascitic Fluid of Women

with Carcinoma of the Ovary

Silburn, P.A.; Khoo, S.K.; Daunter, B.; Hill, R.; Roberts,

T.K.; Mackay, E.V 219

Circulating Immune Complexes in Rats with Metastasizing or

Nonmetastasizing Mammary Tumor

Yoo, T.J.; Balint, J.P., Jr.; Whiteaker, R.S.; Floyd, R.A.;

Kim, U 224

Antibody Responses to Honey-Bee Venom and Monome-

thoxy-Polyethylene Glycol-Modified Honey-Bee Venom in

Mice

Ahlstedt, S.; Björkstén, B.; Åkerblom, E 228

Assessment of Venom-Specific IgG Antibody in Patients

Treated for Hymenoptera Allergy

Gentlesk, M.J.; Hamilton, R.G.; Adkinson, N.F., Jr.; Mans-

mann, H.C., Jr 233

Repetitive Testing and Storage of Human Effector Cells in Natural Killing and Antibody-

Dependent Cell-Mediated Cyto-

toxicity

Hirsen, D.J.; Dubin, B.A.; Malham, L.M 241

The Antigens of Pigeon Breeder's Disease. IV. Detection of

Active Enzymes in Pigeon Dropping Extracts

Krause-Hooyman, L.; Fredricks, W.W 245

Cross-Reactivity of Cat and Dog Allergen Extracts. RAST Inhibition Studies with Special

Reference to the Allergenic

Activity in Saliva and Urine

Viander, M.; Valovirta, E.; Vanto, T.; Koivikko, A. ... 252 Factors Influencing Bonding of

Bromelain Agglutinators and

Their Fab Fragments

Waller, M.; Richard, A.J 261

Detection of Complexed IgE in Sera of Patients Allergic to the

Pollen of Parietaria officinalis

Oreste, U.; Calligaris, V.; Ruffilli, A 267

Phagocytosis Inhibits the Production of $\mathrm{C} 2$ by Human Mono-

cytes

Morrison, L.; Whaley, K

271

Short Communications 
Sodium Diethyl Dithiocarbamate and the Mononuclear Phagocytic System in Guinea Pigs

Neveu, P.J.; Vincendeau, P 276

Adjuvant Effects of Crystalline Silica on IgE and IgGl Anti

body Production in Mice and Their Prevention by the Mac-

rophage Stabilizer Poly-2-Vinylpyridine N-Oxide

Mancino, D.; Buono, G.; Cusano, M.; Minucci, M 279

Enhancement of the Anaphylactoid Reaction in Rats by Phe-

nylalanine Enamine

West, G.B 282

Reverse Enzyme Immunoassay for the Determination of Der-matophagoides pteronyssinus IgE

Antibodies Moneo, I.; Cuevas, M.; Ureña, V.; Alcover, R.; Bootello, A. 285

Book Review 288

News Item 288

No. 4

Original Paper

Trapidil, a Coronary Vasodilator, Inhibits IgE-Mediated Hista-

mine Release from Human Basophils

Morita, Y.; Inokuma, S,; Miyamoto, T 289

Specific Antibody Responses in Rats and Mice after Daily

Immunization without Adjuvant

Ahlstedt, S.; Björkstén, B 293

IV

Contents

Abnormalities of Circulating T Cell Subsets in Atopy: Influence of Specific Immunotherapy Canonica, G.W.; Dirienzo, W.; Cosulich, E.; Ferrini, S.;

Ciprandi, G.; Melioli, G 300

Increase of Mucosal Mast Cells in the Jejunum of Patients Infected with Trichinella spiralis

Gustowska, L.; Ruitenberg, E.J.; Elgersma, A.; Kociçcka, W. 304

Local and Systemic Factors Regulating Mucosal Mast Cells

Pitts, R.M.; Mayrhofer, G 309

Granular Intraepithelial Lymphocytes of the Rat Small Intes

tine. I. Isolation, Presence in T Lymphocyte-Deficient Rats

and Bone Marrow Origin

Mayrhofer, G.; Whately, R.J 317

Studies on Thymocyte Subpopulations in Guinea Pigs. 2. Three

Subpopulations Differing in Rosette-Forming Ability, as

Detected by both Visual and Electronic Counting of Ro

settes

Sandberg, G 328

Fluorescent Berberine Binding as a Marker of Secretory Activ

ity in Mast Cells

Berlin, G.; Enerbäck, L

332

Characterization of a Very High Density Lipoprotein Allergen,

Dpt 4, from the House Dust Mite Dermatophagoides ptero- 
nyssinus

Stewart, G.A.; Butcher, A.; Turner, KJ 340

Inhibition of $\mathrm{T} \gamma$ Rosette Formation by the Sera from Patients

with Systemic Lupus erythematosus. Relation to T $\gamma$-Spe-

cific Antilymphocyte Antibody

Okudaira, K.; Tanimoto, K 346

Effect of Anti-Allergic and Cyclic AMP-Active Drugs on Hista-

mine Secretion from Rat Mast Cells Treated with the Novel

Calcium Ionophore Chlortetracycline

White, J.R.; Pearce, F.L 352

Absence of Complement Activation in vitro by Sodium Meglu-

mine Ioxitalamate

Freyria, A.-M.; Billet, F.; Eloy, R.; Traeger, J 357

In vitro Effects of 13-Cis-Retinoic Acid (Ro 4-3780) and Etre-

tinate (Ro 10-9359) on DNA Synthesis and Fine Structure

of Guinea Pig and Human Lymphoid Cells

Nordlind, K.; Thyberg, J 363

Correlation of Leukocyte Accumulation with Chemotactic Ac

tivity in the Exudate of an Allergic Air-Pouch Inflamma

tion

Kurihara, A.; Ohuchi, K.; Tsurufuji, S 368

Short Communications

Quercetin Inhibits Anaphylactic Contraction of Guinea Pig

Ileum Smooth Muscle

Fanning, M.J.; Macander, P.; Drzewiecki, G.; Middleton,

E.,Jr 371

Effect of Diet on Adjuvant-Induced Disease and Mitogenic

Responses of Fisher Rats

Yiagou, M.; Hadjipetrou-Kourounakis, L 374

Book Reviews 377

Author Index 379

S. Karger · Medical and Scientific Publishers · Basel · München · Paris · London · New York ·

Tokyo $\cdot$ Sydney

Drug Dosage

The authors and the publisher have exerted every effort to ensure that drug selection and dosage set forth in this text are in accord with current recommendations and practice at the time of publication. However, in view of ongoing research, changes in government regulations, and the constant flow of information relating to drug therapy and drug reactions, the reader is urged to check the package insert for each drug for any change in indications and dosage and for added warnings and precautions. This is particularly important when the recommended agent is a new and/or infrequently employed drug.

All rights reserved.

No part of this publication may be translated into other languages, reproduced or utilized in any form or by any means, electronic or mechanical, including photocopying, recording, microcopying, or by any information storage and retrieval system, without permission in writing 
from the publisher or, in the case of photocopying, direct payment of a specified fee to the Copyright Clearance Center (see 'Information for Readers and Subscribers').

(C) Copyright 1983 by S. Karger AG, P.O. Box, CH-4009 Basel (Switzerland) Printed in Switzerland by Buchdruckerei Basler-Zeitung AG, Basel 